\title{
Correction to: Survival of Brucella abortus S19 and other Brucella spp. in the presence of oxidative stress and within macrophages
}

\author{
Jens Jacob ${ }^{1}$ (D) Antje Finke ${ }^{1} \cdot$ Martin Mielke $^{1}$
}

Published online: 22 June 2021

(c) The Author(s) 2021

The article Survival of Brucella abortus S19 and other Brucella spp. in the presence of oxidative stress and within macrophages, written by Jens Jacob, Antje Finke \& Martin Mielke, was originally published Online First without Open Access. After publication in volume 65, issue 5, page 879-894 the author decided to opt for Open Choice and to make the article an Open Access publication. Therefore, the copyright of the article has been changed to $\odot$ The Author(s) 2020 and the article is forthwith distributed under the terms of the Creative Commons Attribution 4.0 International License, which permits use, sharing, adaptation, distribution and reproduction in any medium or format, as long as you give appropriate credit to the original author(s) and the source, provide a link to the Creative Commons licence, and indicate if changes were made. The images or other third party material in this article are included in the article's Creative Commons licence, unless indicated otherwise in a credit line to the material. If material is not included in the article's Creative Commons licence and your intended use is not permitted by statutory regulation or exceeds the permitted use, you will need to obtain permission directly from the copyright holder. To view a copy of this licence, visit http:// creativecommons.org/licenses/by/4.0. Open Access funding enabled and organized by Projekt DEAL.

Publisher's Note Springer Nature remains neutral with regard to jurisdictional claims in published maps and institutional affiliations.
The original article can be found online at https://doi.org/10.1007/ s12223-020-00798-1.

Jens Jacob jacobj@rki.de

1 Robert Koch-Institute, Nordufer 20, 13353 Berlin, Germany 